\title{
Reproductive condition and ovarian atresia in the common kilka (Clupeonella cultriventris) from the Caspian Sea years after a dramatic outbreak of the comb jelly fish (Mnemiopsis leidyi)
}

\author{
NARJES KARIMI ${ }^{1}$, ALI BANI ${ }^{2}$ and SHAHRAM ABDOLMALAKI ${ }^{3}$ \\ ${ }^{1}$ Fisheries Department, Faculty of Natural Resources, University of Guilan, Sowmeh-sara, Iran. \\ E-mail: Narjess_Karimi@yahoo.com \\ ${ }^{2}$ Department of Biology, Faculty of Science, University of Guilan, Rasht, Iran. \\ ${ }^{3}$ International Sturgeon Research Institute, Rasht, Iran.
}

\begin{abstract}
SUMMARY: To assess the reproductive condition of the common kilka, Clupeonella cultriventris, the somatic condition and reproductive characteristics were studied by histological analysis. A total of 800 specimens from the Bandar Anzali coast on the Caspian Sea were sampled. The gonadosomatic index (GSI) for females and males attained maximum values in May in the first period of sampling and in March-April in the second period, suggesting temporal variations in spawning activity. The pattern of oocyte frequency distribution demonstrated that the common kilka is a batch spawner with group-synchronous oocyte development. The estimated relative batch fecundity was 6718 oocytes $\mathrm{g}^{-1}$. A low level of atresia $(4.7 \%)$ during the spawning season showed that this species was in optimal somatic condition. This weakens the hypothesis that abundance of the ctenophore (Mnemiopsis leidyi) in the Caspian Sea, as a food rival for kilka, influences the body condition and subsequently the reproductive capability of this species.
\end{abstract}

Keywords: Caspian Sea, Clupeonella cultriventris, atresia, group-synchronous, spawning season, somatic condition, Mnemiopsis leidyi.

RESUMEN: CONDICIÓN REPRODUCTIVA Y ATRESIA OVÁRICA EN LA KILKA COMÚN (CLUPEONELLA CULTRIVENTRIS) EN EL MAR

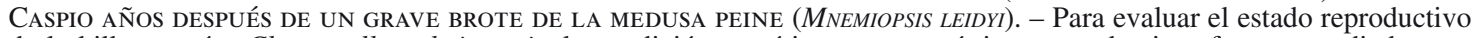
de la kilka común, Clupeonella cultriventris, la condición somática y características reproductivas fueron estudiados por el análisis histológico. Se muestrearon un total de 800 ejemplares de la costa Bandar Anzali en el Mar Caspio. El índice gonadosomático (GSI) para las hembras y los machos alcanza valores máximos en mayo, en el primer período de muestreo y de marzo a abril en el segundo período, lo que indica las variaciones temporales en la actividad reproductora. El patrón de distribución de frecuencia de ovocitos demostró que la kilka común es un ponedor secuencial con el desarrollo de ovocitos sincronizado. La fecundidad parcial relativa estimada fue de 6.718 ovocitos $\mathrm{g}^{-1}$. Un bajo nivel de atresia (4.7\%) durante la temporada de desove mostró que esta especie se encontraba en óptimas condiciones somáticas. Esto debilita la hipótesis de que la abundancia del ctenophore (Mnemiopsis leidyi) en el mar Caspio, como competidor de Kilka por el alimento, influye en la condición corporal y, posteriormente, la capacidad reproductiva de esta especie.

Palabras clave: mar Caspio, Clupeonella cultriventris, atresia, síncrono por grupos, época de desove, condición somática, Mnemiopsis leidyi.

\section{INTRODUCTION}

The common kilka (Clupeonella cultriventris) belongs to the Clupeidae family and is a commercially important species in the Caspian region. It lives in the coastal zone at a depth of less than 50-70 m (Prikhodko 1981, Pourgholam et al. 1996, Fazli and Besharat 1998). Although there is limited information on the 
reproductive biology of the common kilka, a description of the peak spawning time in the Babolsar region, southeast Caspian Sea was made by Naderi et al. 1997. In recent years, the common kilka has become the most abundant clupeid in the commercial catch, after a dramatic decline in the fisheries of another two clupeids: anchovy ( $C$. engrauliformis) and big eye (C. grimmi) (Besharat and Khatib 1993, Pourgholam et al. 1996, Fazli 2007). Overfishing and the competition for food of clupeid fish by comb jelly fish (Mnemiopsis leidyi), an introduced alien ctenophore in the Caspian Sea, are recognized as causative factors for the considerable decline in abundance of clupeid fish (Bilio and Niermann 2004). Heavy competition for zooplankton from $M$. leidyi causes starvation in the clupeid stocks (Kideys 2001).

Egg production and recruitment are mainly associated with appropriate feeding conditions (Lambert and Dutil 2000), and lack of appropriate feeding may result in a reduction of the reproductive fish capability (Rideout and Tomkiewicz 2011). Reproduction in fishes can be suppressed by the starting and subsequent interruption of vitellogenesis due to mass atresia of vitellogenic oocytes (Rideout et al. 2005).

In highly fecund species such as some teleost fishes, some of the changes in the structure of a population can be defined by the reproductive capability (Einum et al. 2003). The variations in reproductive features (e.g. gonad weight, fecundity and spawning strategy) can be affected by biotic or abiotic factors (Fowler et al. 2000) and these factors can potentially affect the reproductive potential (Marshall et al. 1998). Thus, the most essential issue in the reproductive strategy is to increase the reproductive capability, which is in turn related to the availability of energy and parental survival (Wootton 1984, Roff 1992, Pianka 2000). In response to environmental fluctuations, fish follow different strategies and tactics (Balon 1984, Ware 1984) such as regulating fecundity and selecting a suitable spawning season in order to increase their reproductive potential.

Somatic condition, atresia and fecundity are connected in reproductively mature individuals. Fecundity appears to be regulated by the number of atretic oocytes in early or late vitellogenesis, when the energy reserve is insufficient (Rizzo and Buzzoli 1995, Miranda et al. 1999). In the case of heavy food competition between kilka and other organisms, such as ctenophores, body condition and thus reproductive potential may be affected. A previous study (Roohi et al. 2008) revealed significant biomass (up to $58.9 \mathrm{~g} \mathrm{~m}^{-3}$ ) and abundance (up to 1157 individual $\mathrm{m}^{-3}$ ) of $M$. leidyi in shallow and coastal waters of the south Caspian Sea in the period 2001-2006. The present study, performed in subsequent years, examines the reproductive biology of $C$. cultriventris in the south west of the Caspian Sea and enables us to understand the possible effect of $M$. lei$d y i$ on the reproductive output of the common kilka. The main objective was to assess patterns of gonadal development, spawning strategy, batch fecundity and

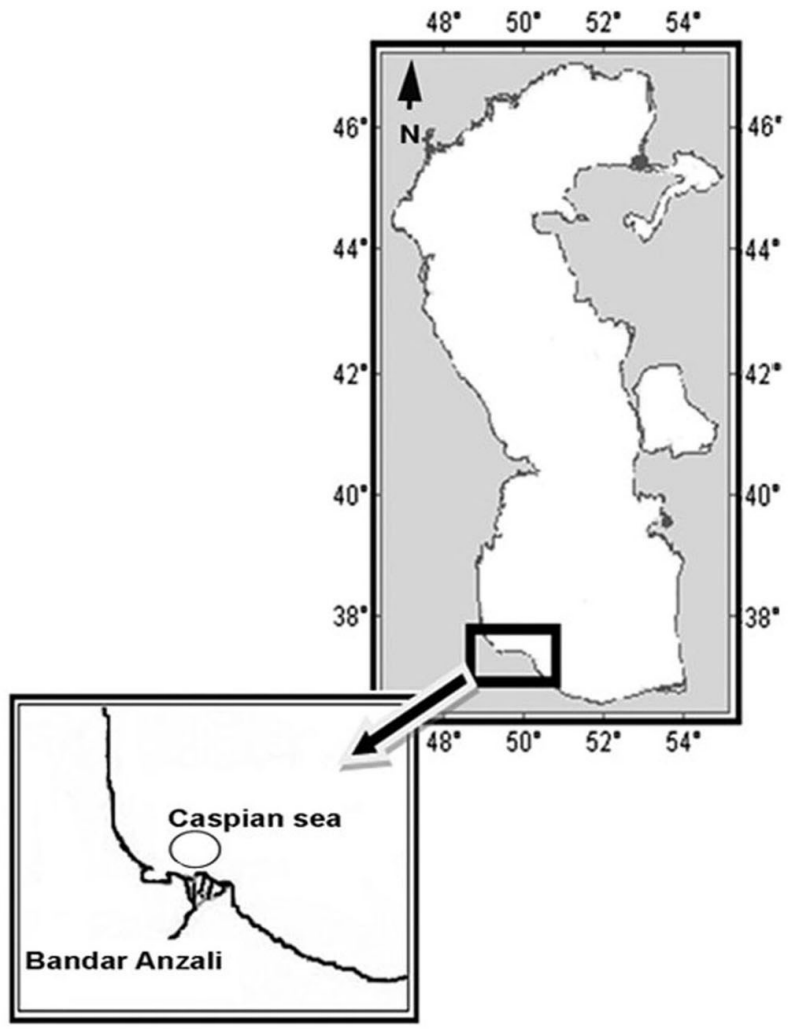

FIG. 1. - Map of the area sampled for the common kilka in the southwest coast of the Caspian Sea (Bandar Anzali) $\left(37^{\circ} 28^{\prime} \mathrm{N}, 4^{\circ} 28^{\prime} \mathrm{E}\right)$.

the occurrence of atresia in the common kilka. Additionally, its somatic condition was determined and compared with that of previous years (1994-1996) in order to assess its relation to reproduction.

\section{MATERIALS AND METHODS}

\section{Sample collection}

A total of 800 common kilka (467 males, 333 females) were sampled fortnightly from Bandar Anzali coastal areas (Fig. 1) at depths of 40-60 metres from March 2008 to May 2009. Additionally, to further monitor gonadal changes on a weekly basis, weekly sampling was performed during the peak of the reproductive season (March, April and May). On each occasion, 30-40 fish were sampled. The sex ratio was closely similar in almost all months except March, April and May, when male fish were dominant. Fishing was done at night, onboard a commercial fishing fleet equipped with cone nets and underwater lights. Fish were stored on ice and dissected in the laboratory within six hours of capture.

All fish were sexed (male or female), measured to the nearest millimetre total (TL) and fork length (FL), and weighed (TW) to the nearest gram. The gonads of each fish were removed and weighed $(\mathrm{GW})$ to the nearest $0.1 \mathrm{mg}$; their maturity was macroscopically staged (Table 1) and they were preserved in formalin (4\%). 
TABLE 1. - Microscopic, macroscopic, and histological staging criteria used for common kilka ovaries (Lowerre-Barbieri et al. 2011a, BrownPeterson et al. 2011). Numbers in parenthesis are the number of kilka in each maturity stage.

\begin{tabular}{|c|c|c|c|c|}
\hline Maturity stage & Category & Macroscopic ovary & $\begin{array}{l}\text { Macroscopic whole } \\
\text { oocyte }\end{array}$ & Microscopic ovarian morphology \\
\hline 1 & $\begin{array}{l}\text { Immature } \\
(24)\end{array}$ & $\begin{array}{l}\text { Small and pinkish } \\
\text { colour. }\end{array}$ & $\begin{array}{l}\text { Unyolked, spherical } \\
\text { and transparent. }\end{array}$ & $\begin{array}{l}\text { Chromatin nucleolar: very small } \\
\text { oocytes. Clear, spherical nucleus } \\
\text { surrounded by a thin layer of } \\
\text { purple-stained cytoplasm. }\end{array}$ \\
\hline 2 & $\begin{array}{l}\text { Primary growth } \\
\text { (62) }\end{array}$ & $\begin{array}{l}\text { Ovaries reddish- } \\
\text { pink and translucent. } \\
\text { Virgin: ovary wall } \\
\text { thin and transparent. } \\
\text { Recovering: ovaries } \\
\text { flaccid and ovary wall } \\
\text { thick and opaque. }\end{array}$ & $\begin{array}{l}\text { Unyolked: spherical } \\
\text { transparent bodies. } \\
\text { Nucleus clear and } \\
\text { brownish in colour. }\end{array}$ & $\begin{array}{l}\text { Perinucleolar: oocyte size increases } \\
\text { because of thick cytoplasm around } \\
\text { a light nucleus, containing few to } \\
\text { many peripheral nucleoli. }\end{array}$ \\
\hline 3 & $\begin{array}{l}\text { Previtellogenic } \\
\text { (39) }\end{array}$ & $\begin{array}{l}\text { Almost length of body } \\
\text { cavity. Ova not visible. }\end{array}$ & $\begin{array}{l}\text { Partially yolked: some } \\
\text { yolk granules appear, } \\
\text { becoming darker with } \\
\text { increased size. }\end{array}$ & $\begin{array}{l}\text { Cortical alveoli: appearance of oil } \\
\text { vesicles in cytoplasm, pink-stained } \\
\text { zona radiata distinguishable at the } \\
\text { end of the stage. }\end{array}$ \\
\hline 4 & $\begin{array}{l}\text { Vitellogenic } \\
\text { (64) }\end{array}$ & $\begin{array}{l}\text { Full length of body } \\
\text { cavity. Ova visible. }\end{array}$ & $\begin{array}{l}\text { Yolked: oocytes } \\
\text { completely opaque } \\
\text { except for the } \\
\text { translucent perivitelline } \\
\text { border. }\end{array}$ & $\begin{array}{l}\text { Vitellogenic yolk: marked increase } \\
\text { in oocyte size. Cytoplasm filled } \\
\text { with yolk granules and oil vesicles. }\end{array}$ \\
\hline 5 & $\begin{array}{l}\text { Oocyte maturation } \\
(91)\end{array}$ & $\begin{array}{l}\text { Ovaries occupy all } \\
\text { available space of body } \\
\text { cavity, transparent } \\
\text { oocytes visible. }\end{array}$ & $\begin{array}{l}\text { Nuclear migration: } \\
\text { parts of oocytes } \\
\text { become translucent as } \\
\text { yolk coalesces. }\end{array}$ & $\begin{array}{l}\text { Nuclear migration: migration of } \\
\text { nucleus to periphery of cytoplasm, } \\
\text { fusion of oil vesicle into the oil } \\
\text { droplet, coalescence of yolk } \\
\text { granules to form uniform plate. }\end{array}$ \\
\hline 6 & $\begin{array}{l}\text { Ovulated } \\
\text { (32) }\end{array}$ & $\begin{array}{l}\text { Large hydrated oocytes } \\
\text { easily expressed with } \\
\text { slight pressure. Ovaries } \\
\text { pinkish and granular. }\end{array}$ & $\begin{array}{l}\text { Hydration: whole } \\
\text { oocytes are translucent, } \\
\text { except for the oil } \\
\text { droplet. }\end{array}$ & $\begin{array}{l}\text { Hydration: yolk granules fused into } \\
\text { a few plates. Thecal cells appear } \\
\text { like a string. }\end{array}$ \\
\hline 7 & $\begin{array}{l}\text { Regressing } \\
(21)\end{array}$ & $\begin{array}{l}\text { Ovaries flaccid and } \\
\text { bloodshot with thick } \\
\text { wall. }\end{array}$ & & $\begin{array}{l}\text { Spent: postovulatory follicles } \\
\text { present. }\end{array}$ \\
\hline
\end{tabular}

The gonadosomatic index (GSI) was calculated using the following formula (Brown-Peterson et al. 2001): $\mathrm{GSI}=[\mathrm{GW} /(\mathrm{TW}-\mathrm{GW}) \times 100]$

The length and weight data of common kilka between 1994 and 1996, corresponding to the years of $M$. leidyi appearance in the Caspian Sea (Bilio and Niermann 2004), as well as the fisheries data were provided by the Guilan fisheries research centre from stock assessment projects (Pourgholam et al. 1996, Fazli and Besharat 1998, Iranian Fisheries Organization data 2011). Sea surface temperatures during the sampling period were supplied by the Bandar Anzali station of the Iranian bureau of metrology (www.weather.ir).

\section{Laboratory processing and histological analysis}

The size-frequency distribution of oocytes within the intact ovaries of 10 females at each stage of maturity was determined using a microscope equipped with a micrometer. Sections 2-3 mm thick were cut from the anterior, middle and posterior sections of the left ovary and different sizes of oocytes (in a Petri dish) were detached using hypodermic needles. Oocytes are rarely perfectly spherical in shape, so the average of large and small diameters of approximately 100-300 randomly selected oocytes were measured under a stereo-microscope (Olympus SZX12, USA) using transmitted light and bright-field illumination. The development stage of each whole oocyte was determined macroscopically using the criteria proposed by Davis and West (1993).

Batch fecundity (GSI) estimates were calculated according to the number of germinal vesicle migration (GVM) stage oocytes at the beginning of the spawning season (Hunter and Macewicz 1985a). Only those fish with undamaged ovaries at the stage of final oocyte maturation (FOM) and showing no sign of postovulatory follicles (POF) or major atresia were considered for BF estimation (Ganias et al. 2003). To quantify the effect of ovary region on the number of oocytes at the FOM stage, $0.02 \mathrm{~g}$ of ovarian tissue from three sections (posterior, middle and anterior) of both left and right ovaries were taken from 10 females at the stage of FOM. Analysis of variance (ANOVA) was used to compare the number of oocytes per gram between subsamples taken from the three sections of each ovary and also between the two ovaries. There was no significant difference in fecundity between left and right ovaries $(\mathrm{F}=1.47 ; \mathrm{df}=1,1301 ; P=0.225)$ but the number of oocytes varied significantly when posterior and anterior sections of each ovary were compared $(\mathrm{F}=984.58 ; \mathrm{df}=2$, 
TABLE 2. - Histological staging criteria of atresia in ovaries of the common kilka (according to Hunter and Macewicz 1985b).

\begin{tabular}{ll}
\hline Atretic stages & Histological characteristics \\
\hline 0 & No $\alpha$ stage of atresia \\
1 & $\alpha$ atresia of yolked oocytes where less than $50 \%$ of yolked oocytes are affected \\
2 & $\alpha$ atresia of yolked oocytes where more than $50 \%$ of the yolked oocytes are affected \\
3 & Almost all (yolked) oocytes affected by atresia. The $\beta$ stage is dominant \\
\hline
\end{tabular}

1) Alpha $(\alpha)$ Stage Atresia: The nucleus is in disintegration, cytoplasmic evidence indicated by a granular, dark basophilic staining and the disintegration of some of the yolk globules. The zona radiata is slowly dissolving. 2) Beta ( $\beta$ ) Stage Atresia: the atretic follicle is a compact structure composed of numerous disorganized granulosa cells surrounded by a thin thecal and blood vessel layer. 3) Gamma $(\gamma)$ Stage Atresia: the granulosa cells contain flocculent material of a light-yellow hue and have nuclei of a very irregular shape; the granulosa cells are surrounded by far fewer thecal cells and blood vessels.

$1301 ; P<0.05)$. Therefore, three $0.02 \mathrm{~g}$ subsamples from the anterior, middle and posterior sections of each right ovary were weighed accurately and used to estimate $\mathrm{BF}$. The average fecundity was estimated from the average number of oocytes in the three sections multiplied by the total ovarian weight $(\mathrm{g})$.

Histological analysis was used to verify the macroscopical maturity stage and occurrence of atresia in ovaries. A longitudinal section and 3-4 transverse sections from preserved left ovaries were dehydrated in an ethanol series, embedded in paraffin, and sectioned at $6 \mu \mathrm{m}$, before staining with Mayer's haematoxylin and eosin. A histological classification of oocytes (Table 1) was made based on the terminology defined by Lowerre-Barbieri et al. (2011a) and the staging criteria from Brown-Peterson et al. (2011). Ovaries were staged based on the presence of the most advanced type of oocyte (Wallace et al. 1987). The entire ovarian section was examined for the presence of POF and the atretic oocytes (Hunter and Macewicz 1985b) (Table 2). Females that had recently ovulated were identified by the presence of POFs. Females that had ceased spawning activity were identified by an absence of hydrated oocytes or POFs and the presence of high proportions of atretic vitellogenic follicles (Hunter and Macewicz 1985b). Ovarian stage of atresia was determined based on the presence of different types of atretic oocytes at the different stages of ovarian recrudescence. The presence of alpha $(\alpha)$, beta $(\beta)$, and gamma $(\gamma)$ stages of atretic oocytes in the ovaries was used for atresia staging. A hundred randomly-selected oocytes from three histological sections of each ovary were assessed to determine the total percentage of the three stages of atretic oocytes in each ovary. The percentage of atretic oocytes in stage 3,4 and 5 ovaries $(n=100)$ was estimated by counting the number of atretic oocytes under intersections of an ocular grid with 16 intersections in 5-10 microscopic fields.

\section{Statistical analysis}

Two-way ANOVA was applied to determine the interaction of gender and month as independent variables with dependant variables of GSI. The Tukey post hoc test was used to identify significant differences between the various means, while the error terms of ANOVA analyses were tested for homogeneity of variance and normality. Geometric mean regression analy- ses were used to describe the relationship between TL and somatic weight (SW). A residual value (actual weight minus predicted weight) for each individual was obtained from these equations and standardized by dividing each residual by the standard deviation of the predicted values. These residual values provided a sizeindependence measure of somatic condition (Jakob et al. 1996, Hayes and Shonkwiler 2001). Variation in the somatic weight of individuals was explored as a function of year (1994, 1995, 1996 and 2008) using a one-way analysis of covariance (ANCOVA), with total length as the covariate. Linear regression was applied to describe the BF-GSI and BF-SW relationships. Statistical analysis was conducted using SPSS (Version 16, Inc., Chicago, IL, USA) and differences of $\mathrm{P}<0.05$ were considered statistically significant.

\section{RESULTS}

Fork length of specimens ranged from 6.5 to 13.5 $\mathrm{cm}$ for females and from 8 to $13 \mathrm{~cm}$ for males. Changes in GSI were dependent upon the combination of gender and month $\left(\mathrm{F}_{\text {gender*month }}=32.91, \mathrm{df}=27,799, P<0.05\right)$. The average GSI increased in both sexes from March and reached its maximum value in May (Fig. 2), while the extent of the increase was noticeably higher in females. The GSI showed a descending trend from July 2008 and fish of both sexes had a relatively low GSI between August (2008) and January (2009). In 2008 the peak of reproductive activity occurred in May, while in 2009 it took place in March.

The diameter of oocytes in stages 2 and 3 was less than $260 \mu \mathrm{m}$ (Fig. 3). Stage 3 ovaries contained oocytes with yolk vesicles in the cytoplasm (Fig. 4a). Stages 4 (Fig. 4b) and 5 (Fig. 4c) ovaries were marked by an increase in oocyte size to 440 and $520 \mu \mathrm{m}$, respectively. In stage 5, large, nucleus-migrated oocytes were apparent (Fig. 3), accompanied by smaller vitellogenic oocytes (Fig. 3). Histological examination of ovulated ovaries revealed the presence of a heterogeneous population of smaller oocytes together with hydrated oocytes (Fig. 4d).

There was no or little evidence of atresia in stages 4 and 5 of maturity. Mature common kilka females exhibited a very low degree $(4.7 \%)$ of atresia in stage 3 of maturity. However, no state 2 and/or 3 atresia was evident in stage 3 and therefore females were classified in state 1 of atresia (Table 2). 


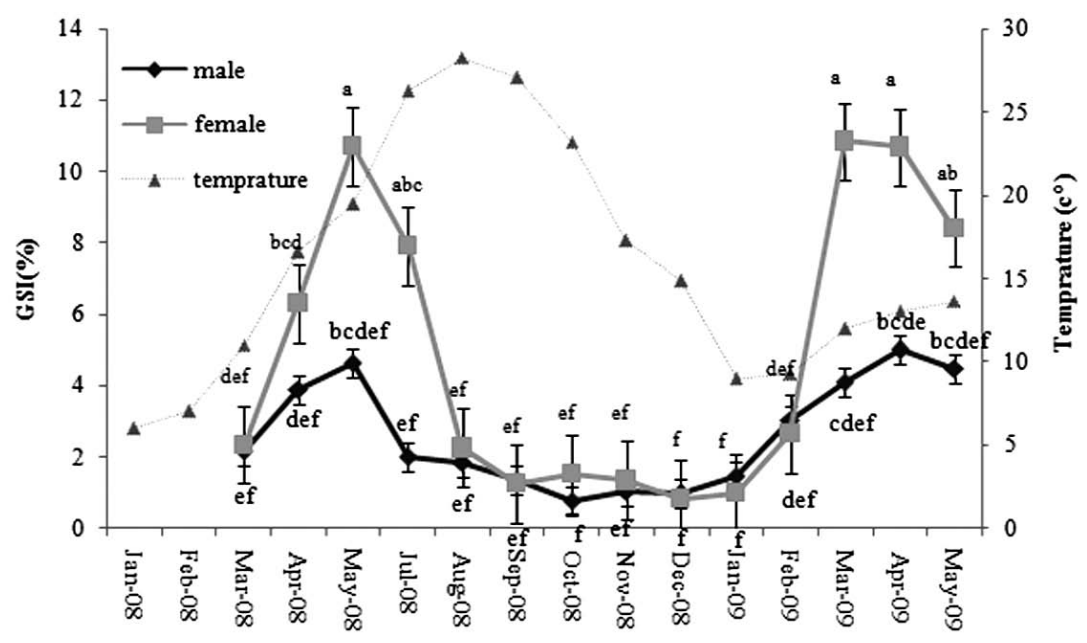

FIG. 2. - Monthly changes in the gonadosomatic index of common kilka and in the average water surface temperatures in the southwest of the Caspian Sea. Values represent the mean \pm SE. Means sharing the same letter are not significantly different.
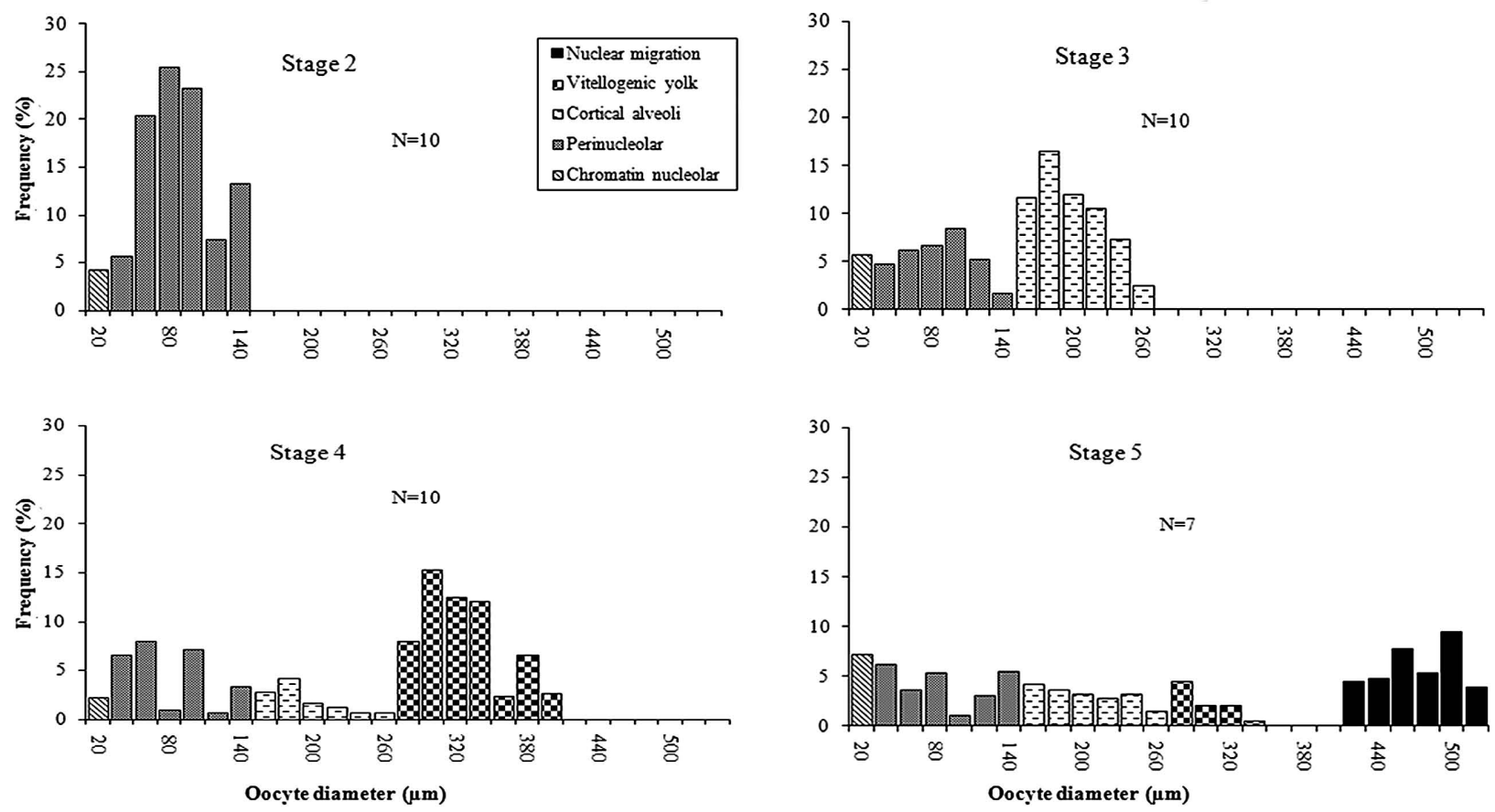

FIG. 3. - Size-frequency distribution of oocyte diameter at stages 2, 3, 4 and 5 of gonad maturity in the common kilka ( $\mathrm{N}=$ sample size).

Batch fecundity ranged from 3646 to 10198 eggs. The estimated mean relative batch fecundity for common kilka (eggs spawned per gram of body weight per batch \pm SE) was $6718 \pm 175$. There was a significant positive relationship between batch fecundity and GSI (Fig. 5a), which is described by the equation $\mathrm{BF}=240.5 \mathrm{GSI}+2940$. However, the relationship between batch fecundity and somatic weight $(\mathrm{BF}=100.7 \mathrm{SW}-5723)$ was found to be very weak and insignificant in the common kilka (Fig. 5b).

Finally, according to Iranian Fisheries Organization data (2011), the total annual kilka catch in the southern waters of the Caspian Sea dropped from 41000-95000 tonnes in 1995-1999 to 78000-15400 tonnes in 20002008. Although the common kilka catch increased from 2003 to 2006, in decreased from 2007 to 2008 (Fig. 6).

\section{DISCUSSION}

The common kilka investigated in this study displayed oocyte development, with two clear clutches of oocytes during the spawning season. In batch-spawning fish, eggs are recruited and ovulated from the population of yolked oocytes in several batches over a protracted period during each spawning season (Murua and Saborido-rey 2003). The spawning batch is separated 

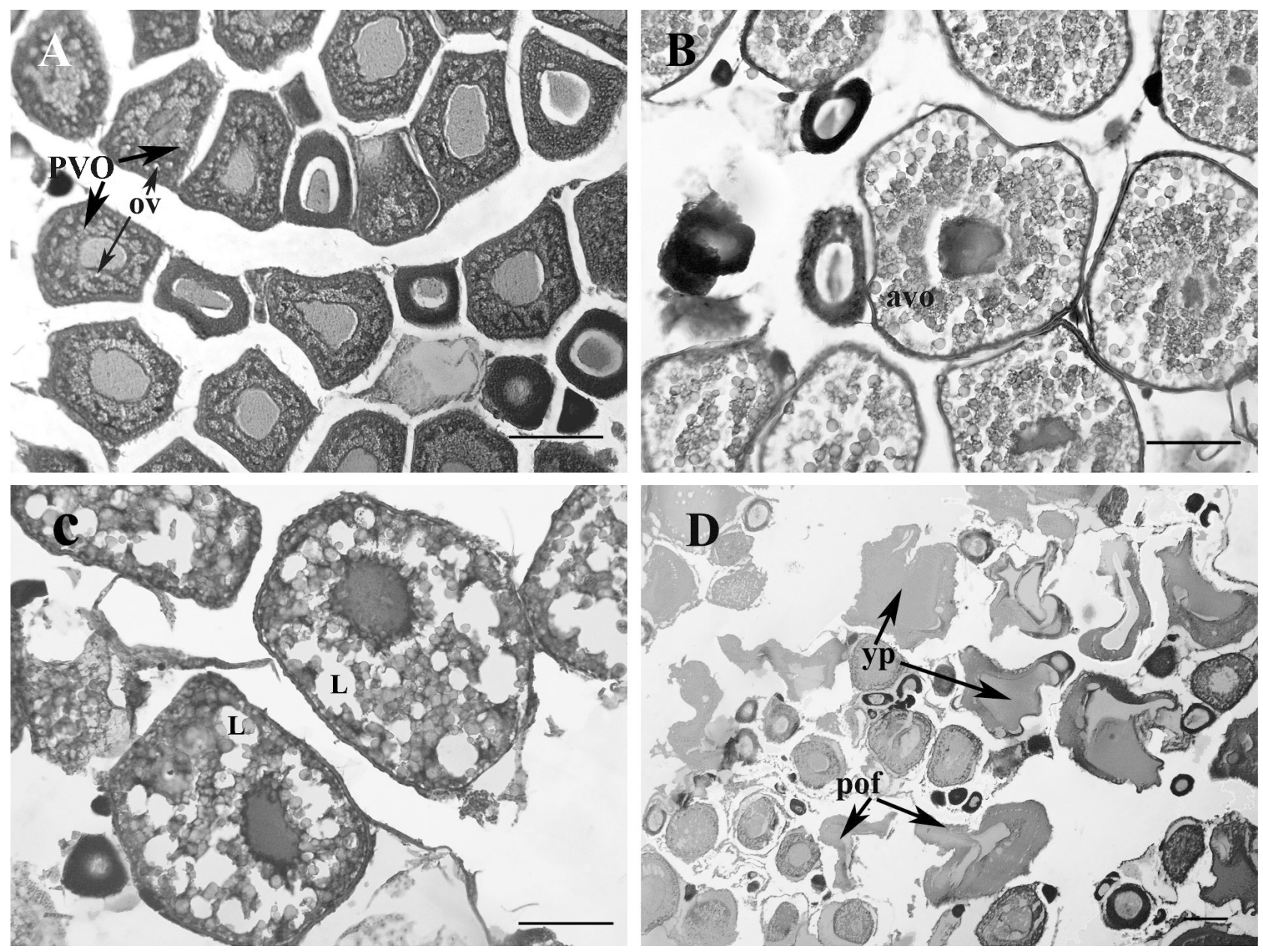

FIG. 4. - Histological sections of oocyte development stages in common kilka ovaries. (A) Stage 3: Appearance of oil vesicles (ov) in the cytoplasm of previtellogenic oocyte (pvo). (B) Stage 4: Marked increase in advanced vitellogenic oocyte (avo). (C) Stage 5: nucleus-migrated and lipids (L) have coalesced to form a large droplet. (D) Stage 6: hydrated oocytes, yolk granules fused into a few plates (yp) and folded postovulatory follicles (pof). Scale bars $0.1 \mathrm{~mm}$.
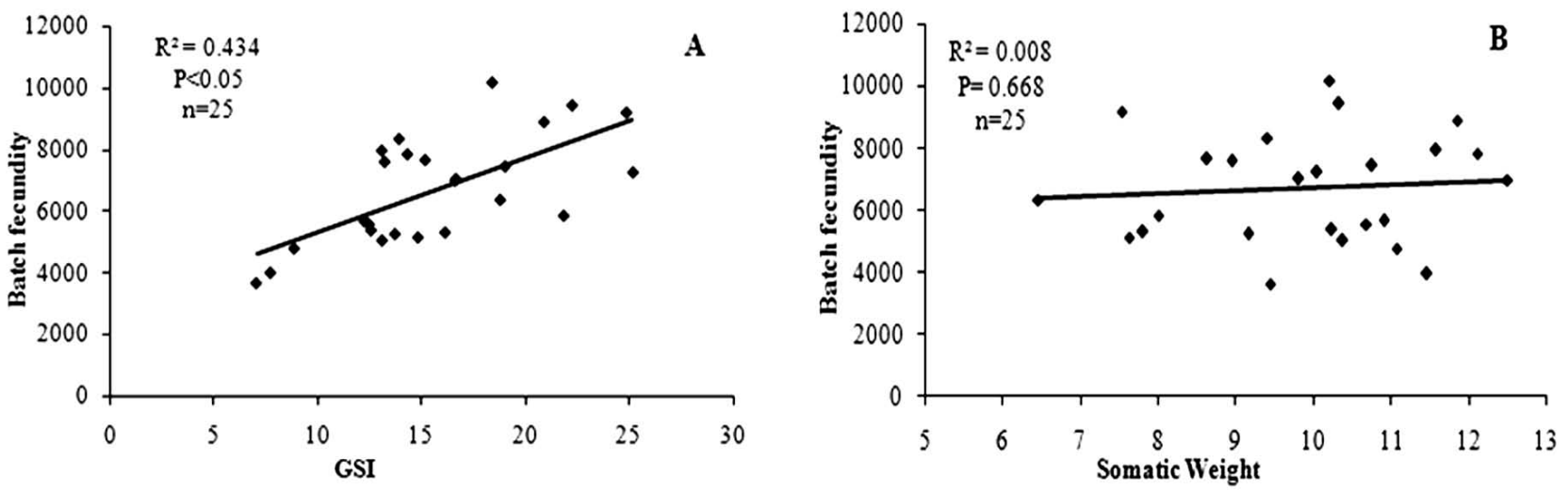

FIG. 5. - Relationship between batch fecundity and GSI (A) and somatic weight (B) in the common kilka (n=25).

TABLE 3. - The average of total weight, somatic weight and residual, as a size-independent measure of somatic condition, \pm SE of female common kilka.

\begin{tabular}{ccccc}
\hline & 1994 & 1995 & 1996 & 2008 \\
$\mathrm{n}=105$ & $\mathrm{n}=89$ & $\mathrm{n}=86$ & $\mathrm{n}=100$ \\
\hline Total length & $9.573 \pm 0.080$ & $9.768 \pm 0.098$ & $10.02 \pm 0.146$ & $10.715 \pm 0.088$ \\
Somatic weight & $6.923 \pm 0.115$ & $7.346 \pm 0.138$ & $7.906 \pm 0.227$ & $9.373 \pm 0.139$ \\
Condition factor & $-0.073 \pm 0.006$ & $-0.089 \pm 0.008$ & $0.033 \pm 0.016$ & $0.114 \pm 0.009$ \\
\hline
\end{tabular}




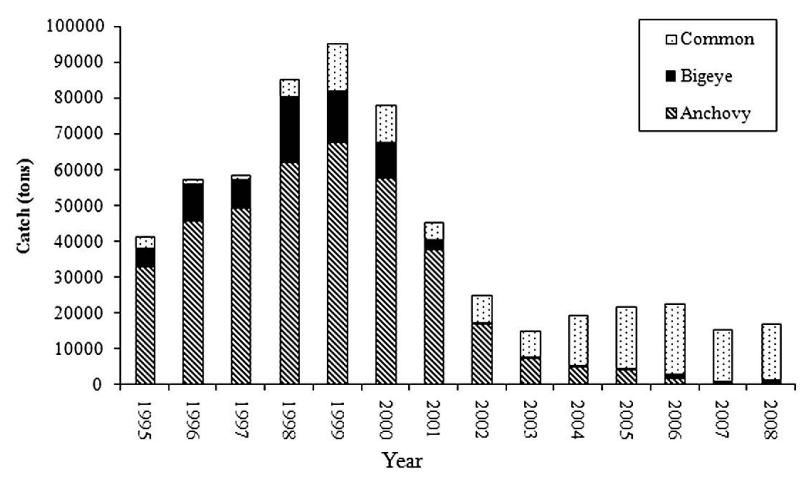

FIG. 6. - Contribution of different kilka species to the total kilka catch from the south Caspian Sea in 1995-2008 (according to Iranian Fisheries Organization data, 2011).

in size and can be recognized from the smaller oocytes at least in late developmental stages. There are reports that in some fish species, such as anglerfish (Lophius litulon), the spawning batches are separated in size and are released once every one or more months during the spawning season (Yoneda et al. 2001). In common kilka, the size-frequency distribution of oocytes in the oocyte maturation stage showed one pioneer clutch of large-size oocytes with nucleus migrated to periphery of cytoplasm. This clutch was accompanied by another clutch of growing oocytes that would be released later in the same spawning season as a second batch. The hypothesis of batch spawning is supported by the presence of various stages of sexual maturity (vitellogenic, oocyte maturation and ovulated) in the spawning period. Additionally, the lack of females with POFs after initial spawning, and their later appearance, indicate another spawning over a relatively long interval. This confirms that the common kilka is a batch spawner and is capable of spawning more than once during the spawning season.

In many fish species GSI, together with the proportion of various reproductive stages, is considered a reliable method for estimating the duration of the spawning period and the peak of spawning activity (Fowler et al. 2000, Brown-Peterson et al. 2001, Lowerre-Barbieri et al. 2011b). In the present study the interannual variation in the initiation and peak of spawning activity of the common kilka was evident. Previous studies of these reproductive characteristics have highlighted the variability at the start and peak of the spawning season. Fazli et al. (2000) showed that in 1996-1998 the peak of spawning activity occurred in April, while in 1999 it occurred in May. Additionally, Prikhodko (1981) reported that the peak of spawning activity for the common kilka is in March and April in the south Caspian Sea. One of the most important environmental factors that can change the timing of the onset of the spawning period is water temperature (Wootton 1982, Lam 1983, Scott and Pankhurst 1992), on which gonadal development usually depends (Kruse and Tyler 1983, Asahina and Hanyu 1983, Conover 1990). The effect of water temperature on the start of spawning has been observed in many fish species. Low water temperature can affect the vitelleogenesis process and cause a delay in spawning time (Kjesbu 1994). Thus, in our study, the lower water temperature observed during the months of yolk formation (January and February) in the first spawning period of 2008 could account for the later spawning activity of the common kilka as compared with the second year in 2009.

The present study showed that the estimated batch fecundity was 6718 oocytes for each gram of body weight. It has been observed that the number of oocytes produced by each fish has a direct connection with its physical and nutritional condition because a reduction in physical energy and inappropriate feeding can lead to a decrease in fecundity (Lambert and Dutil 2000). In female common kilka, the occurrence of atresia (mostly in the stages of and atresia) is observed in the early vitellogenic stages (stage 3 ). This has been recognized as a natural process regulating the surplus of oocytes in the early vitellogenic stages before recruitment into successive stages of development (Lowerre-Barbieri et al. 1996, Tyler and Sumpter 1996) and therefore the occurrence of atretic oocytes does not appear to play a significant role in regulating fecundity.

The lack of atresia at the peak of the reproductive period of the common kilka reflects a high success in the spawning performance, which may be a result of favourable environmental and nutritional conditions (Brown-Peterson et al. 2001) for the common kilka in the south Caspian Sea. In other words, the presence of $M$. leidyi as a food rival for kilka (Kideys et al. 2001) does not at present appear to seriously influence its physical and somatic conditions. The somatic condition of these fish observed in 2008 accounts for a favourable nutritional condition of this region for the kilka. In fact, female common kilka were noticeably in better somatic condition in 2008 (Table 3) than in the period 1994-1996, when M. leidyi appeared in the Caspian Sea. Thus, because of better somatic condition and its positive effect on reproduction in recent years (2008-2009), it is unlikely that the reduction of common kilka stocks is due to the reproductive potential of these fish. After a dramatic decline in the abundance of the other two kilka species (anchovy and big eye kilkas) in 2004 (Fazli 2007), food competition for zooplankton decreased among kilka species, so the common kilka has reached optimal somatic condition in recent years. Janbaz (2006) discovered an increased condition factor for the common kilka approximately ten years after the arrival of $M$. leidyi. Nevertheless, the nutritional state of the common kilka and its relation to somatic and reproductive conditions need to be explored in the future.

Despite the habitat overlap between the common kilka and $M$. leidyi, the results of the present study show that the somatic condition and reproductive potential of the common kilka have not been affected by competition with $M$. leidyi for zooplankton. It has been shown that the reproductive potential of the individual fish within the spawning stock affects recruitment ( $\mathrm{Ri}-$ 
jnsdorp 1991, Kjesbu et al. 1996, Trippel et al. 1997). Therefore, a decline in the abundance of the common kilka is not related to the reproductive capacity of individuals, which was believed to be affected as a result of the outbreak of $M$. leidyi. The reduction in kilka stock is likely to be related to the reduction in the number of adult individuals because of severe fishing. The number of mature individuals is thus insufficient to protect the common kilka population from the problems of overfishing.

\section{ACKNOWLEDGEMENTS}

We would like to thank Azadeh Hatef, Mosayeb Ashori and Mohamad Taghi Zamani for their enormous help in the preparation of this manuscript. Special thanks are owed to Dr. Susan Lowerre-Barbieri for her valuable comments and suggestions. Thanks are also due to the Inland Water Aquaculture Research Institute personnel for their support.

\section{REFERENCES}

Asahina K., Hanyu I. 1983. Role of temperature and photoperiod in annual reproductive cycle of the rose bitterling Rhodeus ocellatus ocellatus. Nippon. Suisan. Gakk. 49: 61-67.

Balon E. K. 1984. Life histories of Arctic Charrs: an epigenetic explanation of their invading ability and evolution. In: Johnson L., Burns B.L., (eds), Biology of the Arctic Charr, Proceedings of the International Symposium on Arctic Charr, University of Manitoba Press, Winnipeg, pp. 109-141.

Besharat K., Khatib S. 1993. Determinate of the commercial catch region in the Iranian coastal zone, 1990-1991. Final report, Mazandaran Fisheries Research Center. 150 pp. (In Persian).

Bilio M., Niermann U. 2004. Is the comb jelly really to blame for it all? Mnemiopsis leidyi and the ecological concerns about the Caspian Sea. Mar. Ecol. Pog. Ser. 269: 173-183.

Brown-Peterson N.J., Overstreet R.M., Lotz J.M., Franks J.S., Burns K.M. 2001. Reproductive biology of cobia, Rachycentron canadum, from coastal waters of the southern United States. Fish. Bull. 99: 15-28.

Brown-Peterson N.J., Wyanski D.M., Saborido-Rey F., Macewicz B.J., Lowerre-Barbieri S.K. 2011. A standardized terminology for describing reproductive development in fishes. Mar. Coast. Fish. 3: 52-70.

Conover D.O. 1990. The relation between capacity for growth and length of growing season: evidence for and implications of countergradient variation. Trans. Am. Fish Soc. 119: 416-430.

Davis T.L.O., West G.J. 1993. Maturation, reproductive seasonality, fecundity, and spawning frequency in Lutjanus vittus (Quoy and Gaimard) from the North West Shelf of Australia. Fish. Bull. 91: 224-236.

Einum S., Fleming I.A., Cote I.M., Reynolds J.D. 2003. Population stability in salmon: species effect of population size and female reproductive allocation. J. Anim. Ecol. 72: 811-821.

Fazli H., Besharat K. 1998. Kilka fishes stock assessment with fishing zones monitoring and hidroacostic method. Fisheries Research Center of Mazandaran Province, 150 pp. (In Persian)

Fazli H., Borani M.S., Janbaz A.A. 2000. The biological characteristics of Clupeonella cultriventris caspia in southern coast and the impacts of Mnemiopsis leidyi invasion on the Caspian ecosystem. Pajohesh. Sazandgi. 69: 87-96. (In Persian)

Fazli H. 2007. Population dynamics and stock assessment of kilka (genus: Clupeonella) in Iranian waters of the Caspian Sea. $\mathrm{PhD}$ thesis. Pukyong National University, South Korea. 145 pp.

Fowler A.J., Mcleay L., Short D.A. 2000. Spatial variation in size and age structures and reproductive characteristics of the King Gorge whiting (Percoidi: Sillahinidae) in South Australian waters. Aust. J. Mar. Freshw. Res. 51: 423-429.

Ganias K., Somarakis S., Machias A., Theodorou A. 2004. Pattern of oocyte development and batch fecundity in the Mediterranean sardine. Fish Res. 67:13-23.

Hayes J.P., Shonkwiler J.S. 2001. Morphometric indicators of body condition: worthwhile or wishful thinking? In: Speakman J.R. (ed.), Body composition analysis of animals. Cambridge University Press, Cambridge, pp. 8-38.

Hunter J.R., Macewicz B.J. 1985a. Measurement of spawning frequency in multiple spawning fishes. NOAA. Technical. Report. NMFS. 36: 79-94.

Hunter J.R., Macewicz B.J. 1985b. Rates of atresia in the ovary of captive and wild northern anchovy, Engraulis mordax. Fish. Bull. 83: 119-136.

Iranian Fisheries Organization. 2011. Year book of Iranian Fisheries Organization statistics for 1994-2010. Research and Development sector of Iranian Fisheries Organization. Tehran, 65 pp. (In Persian).

Iran Metrological Organization. [cited May 2009]. Available from URL: http://www.weather.ir.

Jakob E.M., Marshall S.D., Uetz G.W. 1996. Estimating fitness: A comparison of body condition indices. Oikos 77: 61-67.

Janbaz A.A. 2006. Population dynamics and stock assessment of common kilka (Clupeonella cultriventris) in Iranian waters of the Caspian Sea. MSc thesis. Islamic Azad University Lahijan, Iran, 125 pp. (In Persian)

Kideys A.E., Ghasemi S., Ganinejad D., Roohi A., Bagheri S. 2001. Strategy for combating Menemiopsis in the Caspian waters of Iran. Final Report, July 2001, Caspian Environment Programme, Baku, Azerbaijan.

Kjesbu O.S. 1994. Time of start of spawning in Atlantic cod $(\mathrm{Ga}-$ dus morhua) females in relation to vitellogenic oocyte diameter, temperature, fish length and condition. J. Fish. Biol. 45: 719-735.

Kjesbu O.S., Solemdal P., Bratland P., Fonn M. 1996. Variation in annual egg production in individual captive Atlantic cod ( $\mathrm{Ga}$ dus morhua). Can. J. Fish. Aquat. Sci. 53: 610-620.

Kruse G.H., Tyler A.J. 1983. Simulation of temperature and upwelling effects on the English sole (Parophrys vetulus) spawning season. Can. J. Fish. Aquat. Sci. 40: 230-237.

Lam T.J. 1983. Environmental influences on gonadal activity in fish. Fish. Physiol. 9B: 65-115.

Lambert Y., Dutil J.D. 2000. Energetic variability in prediction by cod, Cadus morhua in relation to spawning level of somatic energy reserves. Can. J. Fish. Aquat. Sci. 57: 815-825.

Lowerre-Barbieri S. K., Brown-Peterson N. J., Murua H., Tomkiewicz J., Wyanski D., Saborido-Rey F. 2011a. Emerging issues and methodological advances in fisheries reproductive biology. Mar. Coast. Fish. 3: 32-51.

Lowerre-Barbieri S.K., Chittenden Jr. M.E., Barbieri L.R. 1996. The multiple spawning pattern of weakfish in the Chesapeake Bay and Middle Atlantic Bight. J. Fish. Biol. 48: 1139-1163.

Lowerre-Barbieri S.K., Ganias K., Saborido-Rey F., Murua H., Hunter J.R. 2011b. Reproductive timing in marine fishes: variability, temporal scales, and methods. Mar. Coast. Fish. 3: 71-91.

Marshall C.T., Kjesbu O.S., Yaragina N.A., Solemdal P., Ulltang Ø. 1998. Is spawner biomass a sensitive measure of the reproductive and recruitment potential of Northeast Arctic cod? Can. J. Fish. Aquat. Sci. 55: 1766-1783.

Miranda A.C.L., Bazzoli N., Rizzo E., Sato Y. 1999. Ovarian follicular atresia in two teleost species: a histological and ultrastructural study. Tissue. Cell. 31: 480-488.

Murua H., Saborfido-Rey F. 2003. Female reproductive strategies of marine fish species of the north atlantic. J. Northw. Atl. Fish. Sci. 33: 23-31.

Naderi M., Fazli H., Afraee M., Ganjian A. 1997. The study of reproduction, fecundity and diet in 3 species of kilka in the southern part of the Caspian Sea (Babolsar region). Iran J. Fish Sci. 6: 65-74.

Pianka E.R. 2000. Evolutionary ecology. Sixth edition. BenjaminCummings, Addison-Longman, San Francisco, $528 \mathrm{pp}$.

Roohi A., Zulfigar Y., Kideys A., Aileen T., Eker-Develi E., Ganjian A. 2008. Impact of a new invasive ctenophore (Mnemiopsis leidyi) on the zooplankton community of the Southern Caspian sea. Mar. Ecol.-Evol. Persp. 29: 421-434.

Pourgholam R., Sedov V., Yermalchev V., Besharat K., Fazli H. 1996. Stock assessment of kilka fishes by hydro acoustic method, 1994-1995. Final report, Mazandaran Fisheries Research Center, 125 pp. (In Persian) 
Prikhodko B.I. 1981. Ecological features of the Caspian kilka (Genus Clupeonella). Scripta Publishing Co. pp. 27-35.

Rideout R.M., Rose G.A., Burton M.P.M. 2005. Skipped spawning in female iteroparous fishes. Fish Fish. 6: 50-72.

Rideout R.M., Tomkiewicz J. 2011. Skipped spawning in fishes: more common than you might think. Mar. Coast. Fish. 3: 176-189.

Rijnsdorp A. D. 1991. Changes in fecundity of female North Sea plaice (Pleuronectes platessa L.) between three periods since 1900. ICES J. Mar. Sci. 48: 253-280.

Rizzo E., Bazzoli N. 1995. Follicular atresia in curimata-pioa Prochilodus affinis Reinhardt, 1874 (Pisces, Characiformes). Rev. Bras. Biol. 55: 697-703.

Roff D.A. 1992. The evolution of life history, theory and analysis. Chapman and Hall, New York, 535 pp.

Scott S.G., Pankhurst N.W. 1992. Interannual variation in the reproductive cycle of the new zealand snapper Pagrus auratus (Sparidae). J. Fish. Biol. 41: 685-696.

Trippel E.A., Kjesbu O.S., Solemdal P. 1997. Effects of adult age and size structure on reproductive output in marine fishes. In: Chabmers R.C., Trippel E.A. (eds), Early life history and recruitment in fish populations, pp. 31-62.

Tyler C.R., Sumpter J.P. 1996. Oocyte growth and development in teleosts. Rev. Fish. Biol. Fisher. 6: 287-318.
Wallace R.A., Selman K., Greeley M.J., Begovac P.C., Lin Y.W., Mcpherson R., Petrino T.R. 1987. Current status oocyte growth. In: Idler D.R., Crim L.W., Walsh J.M. (eds), International symposium on reproductive physiology of fish. St John's: Memorial University of Newfoundland, pp. 167-177.

Ware D.M. 1984. Fitness of different reproductive strategies in teleosts fishes. In: Potts G.W., Wootton R.J. (eds), Fish reproduction: strategies and tactics. Academic Press, New York, pp. 349-366.

Wootton R.J. 1982. Environmental factors in fish reproduction. In: Richter C.J.J., Goss H.J.T. (eds), Reproductive physiology of fish. Pudoc, Wageningen, NL, pp. 210-219.

Wootton R.J. 1984. Introduction: tactics and strategies in fish reproduction. In: Pots G.W., Wootton R.J. (eds), Fish reproduction: strategies and tactics. Academic Press, New York, pp. 1-12.

Yoneda M., Tokimura M., Fujita H., Takeshita N., Takeshita K., Matsuyama M., Matsuura S. 2001. Reproductive cycle, fecundity, and seasonal distribution of the anglerfish Lophius litulon in the East China and Yellow seas. Fish. Bull. 99: 356-370.

Scient. ed.: S. Zanuy.

Received January 5, 2012. Accepted June 19, 2013.

Published online August 1, 2013. 